\title{
O TERROR E A JUSTIÇA
}

\author{
Guilherme Guimarães Feliciano \\ Professor de Direito Penal na Faculdade de Direito da \\ Universidade de Taubaté e doutorando em Direito Penal \\ pela Faculdade de Direito da Universidade de São Paulo. \\ Co-editor do Boletim do Instituto Manoel Pedro Pimentel
}

\begin{abstract}
Resumo:
Em II de setembro de 2001, os EUA foram surpreendidos pelos mais contundentes atentados terroristas de todos os tempos. Em resposta, os norteamericanos mobilizaram forças militares e iniciaram poderosos ataques ao Afeganistão, imputando a Osama bin Laden e à organização Al Qaeda a autoria daqueles atentados. Superada a perplexidade do primeiro instante, apresentamse ao jurista indagações sobre a subsunção jurídica dos atos de destruição em massa perpetrados em solo americano, como também sobre a juridicidade e a legitimidade da represália militar engendrada. Com o propósito de contribuir para esse debate, à luz do Direito Penal e do Direito Internacional Penal, o autor aborda tais eventos do ponto de vista sociológico e jurídico, ferindo aspectos como a natureza dos crimes internacionais (crimes contra a paz, crimes de guerra e crimes contra a Humanidade) à mercê do Estatuto de Roma, de 1998, a fïlosofía penal da legítima defesa e da pena repressiva no contexto internacional, o caráter propedêutico da norma penal internacional, a guerra de agressão e de defesa em face do princípio da igualdade de soberanias, a responsabilidade penal dos Estados (anteprojeto Ago) e a Justiça como valor histórico do Direito.
\end{abstract}

\section{Abstract:}

In 11 of September of 2001 , the United States of America had been surprised by most forceful attempted against terrorist at all the times. In reply, the North Americans had mobilized military forces and had initiated powerful attacks to the Afeganistão, imputing the Osama bin Laden and to the organization Al Qaeda the authorship of those attempted. Surpassed the perplexity of the first instant, appears for the jurist the indagations about the juridical tutelage of the mass destruction acts perpetrated in American ground, as also on the legality and the legitimacy of the produced military retaliation. With the intention to contribute for this debate, to the light of the Criminal law and the Criminal International 
law, the author approaches such events of the sociological and legal point of view, wounding aspects as the nature of the international crimes (crimes against the peace, crimes of war and crimes against the humanity) at the mercy of the Statute of Rome of 1998, the criminal philosophy of self defense and the repressive penalty in the international context, the propaedeutics character of the international criminal norm, the war of aggression and defense in face of the principle of the equality of sovereignty, the criminal responsibility of the States (Ago first draft) and justice as value description of the Right.

Unitermos: crimes contra a Humanidade; crime de guerra; atos ilícitos dolosos; Tribunal Penal Internacional.

Em 11 de setembro de 2001, os EUA sofreram o maior atentado de toda a sua história. Em ação concertada de terroristas que ulteriormente seriam vinculados ao milionário saudita Osama bin Laden (líder da organização paramilitar fundamentalista Al Qaeda e já então integrante da lista dos dez criminosos mais procurados pelo Federal Bureau International $æ$ FBI), as duas torres do World Trade Center, em Nova York, e parte do Pentágono, na Virgínia, foram alvejadas e destruídas por três aviões de carreira preordenadamente seqüestrados para servirem à fatídica colisão, vulnerando a América naquilo que simbolizava, respectivamente, o seu poder econômico (escritórios de mais de 1,5 mil empresas e representações oficiais do Governo norte-americano, incluídos o escritório de alfândega e o Instituto Mundial do Comércio) e o seu poder militar (sede do Ministério da Defesa dos EUA). Um quarto avião seqüestrado, com 38 passageiros, dois pilotos e cinco comissários, caiu no oeste da Pensilvânia, possivelmente em função da reação de usuários e tripulação. O histórico World Trade Center, cuja construção consumiu mais de dez anos e US $\$ 750$ milhões, veio abaixo entre 11 h00 e $11 \mathrm{~h} 30$, com 290 mil toneladas de destroços, outrora distribuídos em 110 andares. Havia "um cheiro doce de queimado, que embrulha o estômagol" Em 20.09.2001, o saldo de mortos era de 233 corpos recuperados no WTC, com 170 corpos identificados, mais 5.422 desaparecidos.

Em represália, os EUA mobilizaram a quinta, a sexta e a sétima frotas da

1. Sérgio Dávila ("Corpos, destroģos e confusão compõem cenário de horror"), de Nova York, in Folha de S.Paulo, 12.09.2001, p.A-9. 
Marinha norte-americana (totalizando, entre outros, três porta-aviões, três fragatas, sete cruzadores, onze destroiers e treze submarinos), o porta-aviões Roosevelt e várias esquadrilhas de combate, incluindo aviões do tipo B-1 e B-52. Em 07.10.2001, iniciaram violentos ataques ao Afeganistão, aos quais aderiu a Real Air Force britânica, com o objetivo declarado de exterminar os campos do Al Qaeda e forçar o Taleban, organização político-religiosa que controla a maior parte do território afegão, a entregar Osama bin Laden; para tanto, engendraram vultosa trama de alianças internacionais, cooptando apoio político (Conselho de Segurança da Organização das Nações Unidas), militar (Inglaterra e França), logístico (Rússia) e estratégico (Turquia, Uzbequistão).

Indagar-se-ia o que este escorço jornalístico interessa a um texto científico ou a uma publicação especializada de literatura jurídica. A par das implicações de ordem político-prognóstica para o Direito Internacional Público e, nesta seara, para o Direito Penal, não se há de olvidar que incidentes de tais proporções suscitam, desde logo, discussões fundamentais sobre o estado de ordem jurídica que informa a malha das relações internacionais e, nessa medida, sobre a subsunção jurídica do fato humano æ nas poucas linhas destrinçadas, expressões como "criminoso" e "terrorista" alhures empregadas, revelam a vocação jurídica indelével do debate æ e o âmbito de le gitimidade da pretensão à retaliação $æ$ a despeito da falácia política que pretende ver, na ação militar norteamericana, mero esforço de defesa. À difícil tarefa de redefinir o terror e a guerra à luz do Direito e, com essa premissa, ferir os dois aspectos precitados, dedico este trabalho.

Do ponto de vista sociológico, não restam dúvidas de que os atentados do dia 11.09.2001 jamais abandonarão o imaginário das nações; tornar-se-ão, com o tempo histórico, mitos negativos que serão lembrados nos bancos escolares e nas atividades lúdicas. Vê-se já nos dias de hoje esse fenômeno, conquanto incipiente, o que traduz a intensidade das impressões sociais desses fatos nas culturas humanas; nos EUA, as estórias em quadrinhos $(H Q) æ$ poderosa manifestação da cultura popular urbana daquele país æadiantam-se aos livros de História e retratam o Capitão América (da Marvel Comics), principal símbolo infanto-juvenil da liberdade e do modo de vida norte-americano, chorando pelos cidadãos americanos mortos no WTC, com a imagem do desastre ao fundo da ilustração, de autoria do brasileiro Mike Deodato Jr. Também o Superman (da DC Comics, maior concorrente da Marvel Comics no mercado norteamericano de quadrinhos) deverá surgir em pôsteres coloridos com a frase "Nós saudamos os heróis da América" ${ }^{2}$ No cinema de Hollywood, especulam-se já

2. Cfr. Diego Assis ("Editoras e desenhistas de HQ unem forças para reerguer $N Y$ ") in Folha de S.Paulo, 21.09.2001, p.E-1 (Folha Ilustrada). 
produções de médio e grande porte inspiradas nos ataques de 11.09.2001, verificandose o mesmo na literatura de ficção. A força do fato social impõe-se, inexorável, às manifestações culturais do homem, ainda qque a contragosto de muitos.

E o fato social traz, necessariamente, a nota da coerção exterior, no sentido de que os indivíduos $æ$ e, a fortiori, os Estados $æ$ agem conforme "o figurino das regras socialmente aprovadas"3 respondendo ao fenômeno social segundo o que dita as bases culturais vigentes, que os precedem em existência; com efeito, fato social é, na eterna acepção de Durkheim, "toda maneira de agir fixa ou não, suscetivel de exercer sobre o individuo uma coerção exterior" " O atentado ao WTC foi, sem dúvida, um fato social de proporções desconcertantes, de tal modo intenso que, ademais de subsumir-se a um figurino social (inapreciável para a hipótese, sem precedentes históricos), tende a impressionar as bases culturais da civilização contemporânea e dimensionar, a partir do que se consolidar em seu derredor, um novo padrão de coercibilidade social, ajustado à irracionalidade do ato terrorista de proporções genocidas $^{5}$ Não por outra razão æ para firmar aquele novo padrão e garantir-lhe legitimidade institucional $\mathfrak{x}$ os EUA não iniciaram os ataques ao Afeganistão sem antes submeter suas evidências ao crivo do Conselho de Segurança da Organização das Nações Unidas e a diversos governos estrategicamente imbricados no conflito.

3. Carlos Benedito Martins, $O$ que é Sociologia, São Paulo, Brasiliense, 1994, p.49. Em sentido similar cfr., na doutrina Penal, Günther Jakobs, La imputación objetiva en Derecho Penal, trad. Manuel Cancio Meliá, Madrid, Civitas, 1996, p.121, in verbis: "Dicho de otro modo: por regla general lo socialmente adecuado precede al Derecho; su legitimación la obtiene del hecho de que constituje una parte da la configuración social que ha de ser preservada. Utilizando de nuevo un ejemplo relativo al tráfico rodado: el hecho de que se considere que el ráfico de los particulares en un día de fiesta es un lujo fácilmente renunciable, o que sencillamente es lo normal, o incluso una manifestación especialmente importante de la libertad general de actuación, es decil; que pueda conllevar; en todo caso, costes reducidos, normales o incluso altos, depende de cómo la sociedad se defina a símisma, y esta autodefinición es parte de la configuración que el Derecho ha de preservar (mientras que esa idiosincrasia no se hay'a convertido en algo internamente contradictorio)". O modelo teórico de Jakobs para a imputação objetiva, segundo pensamos, recebe sensível influxo das teorias sociológicas de Émile Durkheim.

4. E. Durkheim, As Regras do Método Sociológico, S.Paulo, Ed. Nacional, 1972, p.52.

5. Nesse sentido é que, seguindo o exemplo e o discurso norte-americano, o Governo russo de Vladimir Putin predispôs-se a apoiar a operação Internacional antiterrorista liderada pelos EUA, desde que a diplomacia Internacional amenizasse as crítjcas à intervenção militar russa na Chechênia, uıma vez que também os extremistas chechenos empregariam métodos terroristas de combate; da mesma forma, após o assassinato de ministro israelense Rehavam Zeevi (Turismo) por extremistas palestinos (FPLP a Frente Popular para a Libertação da Palestina), o Governo de Israel justificou a ação militar em áreas de ocupação palestina com o argumento de que a Autoridade Nacional Palestina, de lasser Arafat, age como o Taleban afegão, ocultando terroristas e apurando atentados com leniência. 
Fato social dessa relevância, apto a determinar, para adiante, o padrão de alteridade em circunstâncias similares, reclama indelevelmente as vestes talares do Direito. Daí porque a leitura jurídica do fato há de ser feita agora, à mercê da melhor técnica, para nortear as ações humanas subseqüentes; essa convicção, mais que outras idéias quaisquer (como Justiça ou liberdade que, embora legítimas, são imprecisas e ensejam profunda insegurança social), há de informar a atitude dos povos e, sobretudo, das vítimas, para que não se pratique, a pretexto de reprimir um crime, outro ainda mais grave.

Nesse contexto, a ótica jurídica abre ensanchas aos rudimentos que a doutrina universal construiu em torno do chamado Direito Internacional Penal, que se distingue do Direito Penal Internacional pelo seu objeto: o primeiro trata dos denominados crimes internacionais $\mathfrak{x}$ crimes contra a paz, crimes de guerra, crimes contra a Humanidade (inclusive o genocídio, conforme o Estatuto do Tribunal Militar Internacional de Nuremberg, instituído pelo Acordo de Londres de 08/08/1945); o segundo, que Manuel A. Vieira denomina de "Derecho Penal interetatico" abrange os demais ilícitos que, contemplados em convenções internacionais, não são reputados típicos crimes internacionais e submetem-se às jurisdições estatais internas, embora sua repressão universal esteja assegurada por tratados de cooperação" (traço que a doutrina especializada enuncia como princípio da Justiça penal cosmopolita ou universal æ e.g., art.7”, II, “ “" do Código Penal brasileiro ${ }^{7}$ ). Os estudiosos do Direito Internacional Público viam com extremas reservas as pretensões de autonomia de um Direito Internacional Penal, sobretudo pela inexistência de uma Jurisdição internacional permanente para o processo e o julgamento de crimes internacionais; com efeito, o Tribunal de Nuremberg, marco histórico da Jurisdição penal internacional, era um tribunal "ad hoc" constituído especialmente para o processo e o julgamento dos criminosos de guerra dos regimes nazifascistas. Mais recentemente, porém, fora instituído o Tribunal Penal Internacional ("International Criminal Court"), de vocação permanente, cujo estatuto fora adotado em 17.07.1998 por uma conferência diplomática de plenipotenciários da Organização das Nações Unidas. Tal estatuto subordinou à jurisdição do tribunal os mais graves crimes perpetrados em meio à comunidade

6. Manuel A. Vieira, Derecho Internacional Penal y Derecho Penal Internacional, Fundación de Cultura Universitaria, Montevideo, 1969, passim. Cfr. também "A llicitude nos delitos internacionais a Commibuiçāo à construşão científica de um Direito Penal Internacional", de nossa lavra, in Direito ao Avesso n. 02, Sĩo Paulo, RT, março/1997, p.50.

7. Cfr., por todos, Damásio E. de Jesus, Direito Pencl, I o volume, São Paulo, Saraiva, 199, p.ll6. 
Internacional ${ }^{\times}$, a saber, o crime de genocídio, os crimes contra a Humanidade, os crimes de guerra e o crime de agressão (art. $5^{\prime \prime}$ ). Entre os crimes contra a Humanidade, descritos como atos ilícitos dolosos praticados como parte de um ataque sistemático ou anunciado dirigido contra alguma população civil, estão os de assassinio (art. 7, 1, " $a$ ”)); já entre os crimes de guerra estão os ataques intencionais dirigidos contra a população civil ou contra civis individualmente considerados que não tenham tomado parte direta nas hostilidades (art. $8^{\circ}, 2$, " $b(i)$ "'10). Não há dúvidas, pois, de que os atentados terroristas que alvejaram o WTC, na condição de ataques alienigenas orientados direta e sistematicamente a alvos estritamente civis, atentaram contra as relações internacionais, consubstanciando crime contra a Humanidade (pressupondo-se fossem atos beligerantes em tempo de paz) ou crime de guerra (pressupondo-se fossem atos beligerantes em tempo de guerra, como se nos aparenta mais adequado, diante das declarações de Bin Laden e Ayman al Zahri" — admitindo-se que os ataques tenham partido, realmente, da Al Qaeda).

A despeito disso, porém, tais atos não podem ser levados ao julgamento do Tribunal Penal Internacional pelo Estado ofendido - os EUA — simplesmente porque este pais, no afã de garantir sua hegemonia política mundial, não aderiu à convenção de 1998 (Estatuto de Roma), que instituiu aquela Corte; não sendo Estadoparte, não pode submeter aos procuradores internacionais, para investigação e persecução judicial, os fatos criminosos que, sob a Jurisdição material da Corte, foram perpetrados em seu território (arts. 12 e 14). Ademais, tampouco os acusados - o Taleban, Bin Laden e a Al Qaeda - sujeitar-se-iam às leis internacionais ou à jurisdição da Corte $^{12}$ Restou à América, por conseguinte, a ação militar unilateral, informada por um discurso ético e legalista e pela cooptação política de Estados, direta ou

8. "(...) the most serious crimes of concern to the international community as a whole"

9. "For the purpose of this Statute, 'crimes against humanity' means any of the following acts when committed as part as of a widespread or systematic attack directed against any civilian population, with knowledge of the attack: (a) Murder (...)"

10. "For the purpose of this Statute, 'war crimes' means (...) (b) Other serious violations of the laws and customs applicable in international armed conflict, within the established framework of international law, namely, any of the following acts: (i) Intentionally directing attacks against the civilian population as such or against individual civilians not taking direct part in hostilities"

11. Em fevereiro de 1998, Bin Laden lançou decreto religioso - fatwa - para que muçulmanos matassem norte-americanos e seus aliados. Ayman al Zahri, da cúpula da Al Qaeda e do Jihad islâmico do Egito, prometeu vingança contra EUA e alertou os aınericanos para que aguardassem a guerra, logo após a resposta militar americana aos atentados nas Embaixadas do Quênia e da Tanzânia, nos campos do Sudão e do Afeganistão (agosto de 1998). 


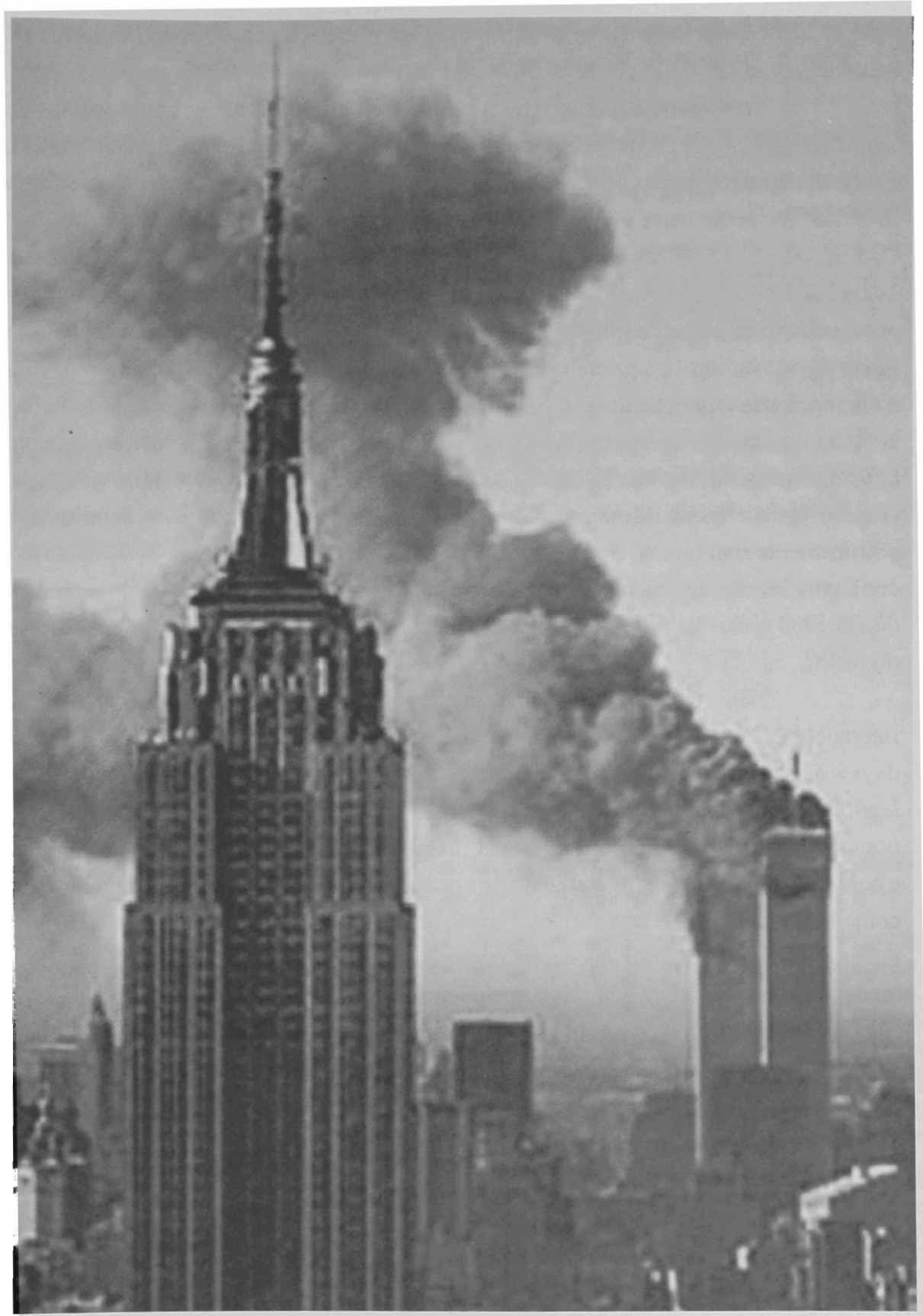

O terrorismo é capaz de realizar o inimaginável em realidade. 
indiretamente interessados no conflito; nada, porém, afeiçoado ao Direito Internacional Penal tal como alvitrado por seus pensadores.

Eis, pois, o que se tem: a reação militar e o discurso, como formas de impor ao delinqüente Internacional a justa repressão por seu ilícito. Justa repressão. Como se entender, nesse contexto injurídico (porque alheio à apreciação de uma Corte Internacional permanente), o ideal de Justiça? O que é justo em uma guerra de agressão? Os militares norte-americanos pretenderam batizar a reação militar aos atentados de 11.09.2001 como "operação Justiça infinita" abandonando depois a expressão, por provocativa aos olhos da população islâmica, para adotar a denominação "operação liberdade duradoura"; a primeira expressão, contudo, reflete meihor o espírito de luta e vingança que tomou de assalto significativa fração do povo norte-americano, ferido em sua integridade e em seu orgulho. Com efeito, toda reação infinita é necessariamente injusta, como toda "Justiça infinita" há de ser, em certo momento, pura e fria vingança. O quão justo é bombardear um país em escombros, economicamente debilitado e politicamente sem rumos, com reflexos nefastos - ainda que indiretos — à população civil, para homenagear a memória de outros tantos mortos nos atentados de setembro de 2001 ? O quão "infinita" pode ser a resposta justa, para não desbordar dos limites do justo?

Tais indagações vão além da mera argüição jurídica, nos lindes do Direito Internacional Penal. Remetem-nos, adiante, à própria filosofia Penal e à própria natureza da pena repressiva, seja como dever-ser, seja como conveniência. De fato, porque de legítima defesa, como se anunciara de início, não é convincente dizer-se tratar. A reação norte-americana foi planejada, concertada, precedida de ajustes estratégicos, econômicos e políticos; não se assemelha àquilo que, na ordem Internacional, tende a ser reconhecido como legítima defesa: ataque armado injusto e atual, "até que o Conselho de Segurança tenha tomado as medidas necessárias para a manutenção da paz e da segurança internacionais"'13 Sobre a atualidade da legítima defesa, é da doutrina universal que "es actual la agresión inminente, la que se realize entonces y la que persiste aún" sendo que "también perdura la agresión si, aun habiéndose producido ya la lesión del interés protegido, cabe todavia anularla total o parcialmente mediante una acción contraria que siga inmediatamente al ataque"'14. Na espécie, porém, os EUA iniciaram sua reação militar mais de vinte e cinco dias após os atentados de 11 de setembro,

12. Cfr. Márcio Senne de Moracs ("Lei Internacional nào impede retaliação, dizem analistas"), in Folha de S.Paulo, 23.09.2001, Caderno Especial (Guerra na América), p.04.

13. Art. 51, da Carta das Naçõcs Unidas, assinada a 26.06.1945. 
quando não mais era possível anular total ou parcialmente a lesão ao bem jurídico, e sem qualquer intenção de subordinar-se às medidas alvitradas pelo Conselho de Segurança da ONU para a manutenção da segurança Internacional; o Conselho de Segurança foi consultado apenas para dar chancela política à agressão armada ${ }^{15}$ Não houve, pois, a atualidade necessária para que a operação militar seja reputada ato de legítima defesa coletiva (haja vista que também a Inglaterra, conquanto não atingida diretamente pelos atentados, participou dos primeiros bombardeios); tampouco houve observância ao art. 51, da Carta das Nações Unidas, tendo em vista que as ações militares não são medidas do Conselho de Segurança, mas medidas unilaterais norte-americanas. Também não havia hipótese clara de autodefesa, se não existia uma perspectiva séria de agressão continuada (o planejamento lento e metódico dos ataques ao WTC e ao Pentágono, assim como a própria característica das ações terroristas, apontavam para a natureza episódica do atentado) e tampouco a certeza de que os ataques ao Afeganistão fariam cessar alguma forma de beligerância (uma vez que os ataques não partiram de solo afegão e sua autoria não foi avocada pelo Afeganistão) ${ }^{16}$

Sendo, pois, pena (e o disseram as mensagens emitidas na guerra psicológica norte-americana: "Nós vamos caçar' e punir esses terroristas. Eles pagarão com sangue"17), em que medida pode ser aplicada e executada pelo Estado norteamericano, tanto mais quando os "réus" - Osama bin Laden e a Al Qaeda — negam participação nos atentados e o Estado que lhes dá guarida — o Afeganistão — não tem acesso às evidências do suposto envolvimento criminoso de seus aliados? ${ }^{18}$

14. Hans-Heinrich Jescheck, Tratado de Derecho Penal - Parte General, trad. José Luis Manzanares Samaniego, 4 a ed., Granada, Comares, 1993, p.307. Note-se que "no Direito Penal, a legítima defesat pressupõe o uso moderado dos meioss indispensáveis a fuzer cessar a agressão injusta, atual ou iminente. Esse conceito pode ser trasladado para o plano do Direito das Gentes, inclusive, com apoio na lişão de Paul Fauchille, para quem só se pode admitir o exercício do Direito de defesa do Estado diante de 'uma agressão injusta, contrária ao Direito e contra a qual o emprego da violência é o ́único recurson possivel'” (Gilda Maciel Corrêa Meyer Russomano, Direito Internacional Público, lo v., Rio de Janeiro, Forense/ Universidade Federal de Pelotas, 1989, pp.336-337).

15. De fato, o Consclho de Scgurança limitou-se a reputar convincentes as cvidências carrcadas pelos EUA, reproduzindo a exigência de que o Taleban entregasse Osama bịn Laden (cfr. Folha de S.Paulo, 19.09.2001, p.A-1).

16. Em scntido contrário, confiram-sc as opiniões de Thomas C. Heller, da Universidade Standford, c de Allan A. Rayan, da Universidade Harvard (Folha de S.Paulo, 23.09.2001, Caderno Guerra na América, p.04).

17. Cfr. Folha de S.Paulo, 19.10.2001, p. A-11 (Folha Munclo): "O Pentágono divulgou mensagem transmitida no Afeganistão em que orienta soldadlos do Taleban a se entregarem 'às forças dos EUA', no mais forte indicio até agora de que os norte-americanos já têm, ou terão em breve, tropas para combate 
É do escólio de Stamatios Tzitzis ${ }^{19}$ que, na concepção kelseniana, cujas raizes estão em Thomas Hobbes, a parte vindicativa da lei obriga o magistrado a punir devido a um ato ilegal, de tal forma que a norma jurídica implica um sollen (dever-ser) dirigido à autoridade competente - o magistrado — para que a respectiva sanção seja executada. A significação jurídica de um ato (sein) tem como validade uma norma; nessa medida, os atos ilícitos (sein — ser) preordenam o dever-ser da punição (sollen). A condição da sanção não é, pois, a obrigação jurídica, mas o comportamento antijurídico, porque o comportamento juridicamente prescrito não é o comportamento devido; devida é, na hipótese, apenas a sanção. Tal é o positivismo jurídico, que justifica desde o mais estrito legalismo até os mais sangrentos regimes (a exemplos das leis de limpeza étnica e segregação do III Reich e do apartheid sul-africano, ambos regimes condenados pela comunidade Internacional). Michel Valley, com melhor propriedade, situa a análise nas antípodas destas idéias; inspira-se no aristotelismo tomista e na filosofia helênica para substituir o sollen pelo deon - a conveniência. O Direito nãotraduz um fiat, i.e., uma obrigação a cumprir, mas antes indica uma realidade, de modo a preordenar cada qual àquilo que lhe convém segundo o seu mérito. $O$ magistrado, assim, não se limita a reconhecer a sanção como dever-ser irretorquível, articulado pelo mundo das coisas (sein); ao revés, ele devassa uma região do ser negligenciada em tempos de nominalismo, a saber, a esfera do justo concreto: cabe-lhe dizer o que pode ser percebido como justo nas relações sociais, assim como ao poeta cabe identificar o belo apercebido nas coisas. $\mathrm{O}$ justo, como valor, emana da norma e deve ser apreendido como tal, mas também deve ser perquirido nas relações concretas como aspecto possível do ser e objeto ideal do Direito; não-traduz, porém, uma regra de ação automática, assim como se afirmar o quão bela é a sinfonia em sol menor de Mozart não-significa que todos devam, indistintamente, agradar-se dela ou aplaudi-la. Na feliz expressão do autor, "o dizer do dikaion indica a parte que diz respeito propriamente a cada um,

em solo afegão". As mensagens, transmitidas cm freqüências de rádio pclo aviāo EC-130 cm pashtu c dari (línguas oficiais do pais), foram dirigidas aos civis afcgãos ("os alvos da ação militar não são vocês, honoráveis habitantes do Afeganistão, mas aqueles que os oprimes e os transformam em escravos" ctc.) c aos soldados do Talcban ("vocês garantiram sua própria morte"; "nossas forças são maiores, mais ágeis e mais fortes, com armas mais modernas e tropas mais bem treinadas" ctc.).

18. Cfr. Folha de S.Paulo, 23.09.2001, Caderno Guerra na América, p.01: “(..) o Taleban rejeitou o ultimato para entregar Osama bin Laden. 'Se os americanos têm evidência (...). devem apresentá-la', afirmou o embaixador do Taleban no Paquistão, Abdul Salam Zaeef. (...). Em pronunciamento feito em árabe, acrescentou que os Estados Unidos criaram 'muitos inimigos', e que Bin Laden não seria o maiordeles").

19. Stamatios Tzitzis, Filosofía Pencl, trad. Mário Ferrcira Monte, Porto, Legis Editora, 1998, pp.27-35. 
nomeia, portanto, a diferença na partilha justa. A diferença que faz o "próprio de cada um deriva da propriedade do justo, já que o justo distribui a cada um aquilo que lhe convém (portanto o seu próprio) segundo o seu mérito"; dai concluir que "a punição do culpado é uma exigência da Justiça que ultrapassa o campo das normas juridicas" porque "a regra Penal não implica um simples indicativo que inspira fragilmente o juiz para fazer a parte das coisas. A regra penal mostra, no sentido do verbo deiknymi, o que é injusto" Dito de outro modo, "a regra Penal incita os homens a uma certa conduta, assinalando o que é justo e o que não é; ela mostra o caminho da ética juridica e a seguir; e as conseqüencias da desobediência. Nesse sentido, não é nem puramente normativa, nem inteiramente indicativa, mas, antes de mais nada, propedêutica: ela indica, instruindo sobre o porquê, o dever-ser" (g.n.). Essa preleção é particularmente importante à vista dos fatos ora comentados: os deploráveis atentados de 11.09.2001, decerto antijurídicos, não se bastam por si mesmos à conclusão de que os responsáveis e seus coadjuvantes mereçam qualquer sanção, como sollen autoexeqüível imanente ao Direito público de autodefesa; não é devida qualquer sanção, mas a sanção justa, proporcional, aplicada pelo juiz investido desta competência e/ou à luz das garantias mínimas de defesa do acusado. A norma Penal - e também a norma Penal Internacional, porque a ela se reporta, em tese, o Governo norte-americano, sempre que evoca expressões como "Justiça" e "liberdade" ou metáforas maniqueístas como "batalha do bem contra o mal" - instrui sobre o dever-ser e seu fundamento ético, o que a torna propedêutica e não meramente normativa ou indicativa; executar sua sanção em desacordo com seu fundamento é agir, pois, à sua margem.

Dentro dessa lógica, e em vista do que dispõe o preâmbulo ("...) reafirmar a fé (...) na existência de direitos iguais (...) entre nações grandes e pequenas") e o art. $2^{\circ}, \S 1^{\circ}$, da Carta de São Francisco ("A Organização é baseada no princípio da igualdade soberana de todos os seus membros"), óbvio está que um país, ainda quando covardemente agredido (ressalvada a hipótese do art. 51, da Carta, única eximente de ilicitude nos atos de beligerância Internacional ${ }^{20}$ mas inocorrente "in casu"), não pode se arvorar em órgão de investigação, julgamento e execução de pessoas e Estados soberanos, agindo ao seu inteiro alvitre e dosando a pena ao sabor da opinião pública interna e/ou exterior. Tal procedimento avilta qualquer padrão de legitimidade jurídica na ação militar armada, tornando-a tão-somente mais uma guerra de agressão, proscrita pela Carta de São Francisco (art. $2^{\circ}, \$^{\circ}$ ) e pelas convenções de Genebra, de $1949^{21}$. A retórica da ética jurídica não responde aos anseios internacionais de Justiça, quando

20. Cfr., nesse scntido, “A llicitude...", op.cit., p.58. 
não lhe corresponde uma ética engajada na ação militar, mormente porque a operação de ataque ignora o primeiro bastião da Justiça universal: o devido processo legal.

Sobre esse tema, de rara felicidade editorial que reconhecia ser "cruelmente irônico que um regime que jamais teve o menor apreço pelo devido processo legal, como é nitidamente o caso do Taleban no Afeganistão, se apegue agora a ele para explicar por que não pretende entregar o milionário saudita Osama bin Laden aos Estados Unidos 22 " Realmente, "apresentar evidências faz, sim, parte do devido processo legal"; logo, ao exigir dos EUA a exibição das evidências contra Bin Laden para somente então o render, o Taleban reclamava para si - menos por convicção que por estratégia - a observância de um dos princípios mais caros ao mundo ocidental civilizado, insito àquele caráter propedêutico da norma Penal. Como insinua o editorial, em idênticas circunstâncias, mas sem o mesmo ingrediente emocional, um juiz norteamericano - sob cuja cultura cunhou-se a expressão "due process of law" — não aceitaria o argumento do sigilo, inclinando-se pelo cumprimento integral dos consectários do devido processo legal (inclusa a exibição das provas às autoridades afegãs). Desse modo, abstraem-se os fundamentos do Direito para fazê-lo valer apenas no que aproveita ao ofendido, a um tempo juiz e executor; falseando-se a regra jurídica para legitimar um discurso de autodefesa justa, aproxima-se a ação da mera retaliação militar. A ofensiva contra o terror, identificado como o "mal". é praticada sem maiores critérios, à margem de garantias fundamentais que devem ser respeitadas no Direito interno como no Direito internacional, ressalvadas as exceções legais ou consuetudinárias; no plano internacional, as soberanias não podem ser simplesmente ignoradas, porque também os Estados têm, na ordem jurídica internacional, direitos essenciais ou fundamentais: o Direito à existência e ao legitimo desenvolvimento como Estado (Le Fur), açambarcando direitos acessórios (igualdade jurídica, domínio exclusivo sobre o território nacional, legação ativa e passiva etc. ${ }^{23}$ ).

Isso tudo nos conduz ao caráter polemogêneo do Direito Penal como Direito de punir, que "revela a guerra em nome da inocência da vitima contra os maus

21. Cfr., nesse sentido, J. Francisco Rezek, Direito Internacional Páblico, 4a ed., São Paulo, Saraiva, 1994, pp.377/378: "A Carta de São Francisco ditaria finalmente, em 1945, a proscrişão da guerra e de" fenômenos variantes (...) A guerra repontava agora como ilicito Internacional, o que por certo fazia caduc:ar uma série de normas - notadamente avensadas na Haia - sobre o ritual militar; mas nãa varria da cena Internacional a perspectiva da eclosão de conflitos armados näo menos sangrentoss e duradouros que as guerras declaradas de outrora. Impunha-se atualizar e ampliav o acervo normativo humanitário"

22. Folha de S.Paulo, 21.09.2001, p.A-2.

23. Cfr. Corrêa Mcycr Russomano, op.cit., pp.331-341. 
efeitos do acto culpado 24 "; a pena opera pela paz, em nome do restabelecimento de uma harmonia perturbada no universo e na alma do indivíduo, lutando contra todo o elemento de anarquia, i.e., contra todo ato que, imbuído de vontade rebelde, tende à desordem do crime. O Direito Penal, parafraseando o apóstolo Paulo, combate o bom combate: guerreia pela paz (polemogêneo: "polemos" [= guerra] + "gennân" [= engendrar $] \Rightarrow$ engendrar a guerra contra o ilícito e pela paz), seja internamente, seja em se o admitindo naquele âmbito - perante a comunidade Internacional. A retórica norte-americana sugere, na figura do "bem contra o mal" a luta pelos inocentes; evoca, pois, o caráter polemogêneo do Direito de punir. Mas atendê-lo-á no curso dos acontecimentos e sob o testemunho da História? A operação antiterror perpetrada mediante intervenção militar em Estados soberanos (Afeganistão, Somália e Sudão) servirá ao propósito da paz ou, antes, incitará os povos de tradição muçulmana ao ódio antiamericano e à assimilação dos discursos fundamentalistas de jihad (guerra santa)? Nesse último quadro - de maior probabilidade, à mercê das reações populares documentadas nas diversas nações islâmicas e da onda de bioterrorismo (anthrax) inaugurada após os eventos de 11.09.01 — o Direito de punir, tal como exercitado, não estará atendendo ao seu teleos fundamental; estará, ao contrário, contraproduzindo mais celeuma e desordem, com detrimento à ordem pública Internacional e à tranqüilidade social — propósitos do polemos da pena. Não será, pois, polemogênea, mas polemogenética - fonte primeira da guerra. Esse estado de coisas é o sintoma mais claro de que a ação militar norte-americana tem sido percebida, notadamente pelas populações muçulmanas, como castigo moral e não-sanção jurídica; moral, como moral é a jihad islâmica e toda forma de fundamentalismo religioso. Com efeito, é condição indispensável à pena como sanção jurídica a sua individualização e racionalização, segundo a máxima "nulla poena sine culpa"; já para a Moral, a máxima fundamental inverte-se, para ser enunciada como "nulla culpa sine poena ${ }^{25}$ ": admitese o castigo de inocentes, circunstancial (persecução de culpados sem exibição de provas) ou indissociável (civis afegãos) da reação ofensiva, para a expiação do crime e a satisfação da sanha coletiva. Nesse caso, o ofendido nivela-se ao ofensor e o ingrediente do justo é expurgado do contexto da ação, tornando-a injurídica.

Quanto ao Afeganistão, acusado de ocultar terroristas e secundar suas ações pelo mundo, uma breve digressão se impõe. O Direito Internacional Público

24. Stamatios Tzitzis, op.cit., pp.37-5I.

25. Idem, p.50. 
ainda não admite a responsabilidade criminal do Estado, à vista do que dispõe o art. 25 (1) do Estatuto de Roma ("The Court shall have jurisdiction over natural persons pursuant to this Statute"); logo, suas responsabilidades, aferidas no plano Internacional, cingir-se-iam à esfera do indenizável: responsabilidade dos Estados por atos ilicitos civis internacionais, a exemplo do que prescrevem a Convenção sobre Responsabilidade Civil por Danos Nucleares (Viena, 1963), a Convenção de Bruxelas, de 1971, a Convenção das Nações Unidas sobre o Direito do Mar (1982), a Convenção Internacional sobre Responsabilidade Civil por Danos Causados por Poluição por Óleo (Bruxelas, 1969), a Convenção sobre a Responsabilidade por Danos Causados por Objetos Especiais, de 1972, etc. A perspectiva doutrinária, todavia, antevê a responsabilidade criminal, mormente aos influxos da chamada doutrina penalistica, baseada na idéia de unidade de desenvolvimento entre o Direito interno e o Direito internacional; por esse pensamento, não há diversidade de estrutura ou base social entre aqueles dois sistemas jurídicos, mas apenas um estado diverso de desenvolvimento: enquanto o Direito interno adianta-se em fase avançada de evolução, o Direito internacional encontra-se em fase primitiva. Logo, à doutrina cumpriria empenhar-se em tornar mais célere o desenvolvimento do Direito Internacional, de forma que o crime Internacional do Estado aparece como instituto "de jure condendo" subordinado à criação de estruturas ainda inexistentes, como um tribunal Internacional Penal e um código Penal abrangentes da responsabilidade criminal do Estado ${ }^{26}$. Nesse sentido, aliás, encaminhava-se o Projeto da Comissão de Direito Internacional das Nações Unidas sobre Responsabilidade Internacional dos Estados, baseado nos anteprojetos de Ago, Riphagen e Arangio-Ruiz, cujo art. 19 (2) reconhece que "o fato internacionalmente ilicito resultante de uma violação por um Estado de uma obrigação Internacional tão-essencial para a salvaguarda de interesses fundamentais da comunidade Internacional que sua violação esteja reconhecida como crime por essa comunidade Internacional constitui um crime Internacional 27 " Hoje, porém, identificada a cumplicidade do Estado afegão, não se poderia mais que instá-lo, no limite, ao ressarcimento dos EUA e demais Estados prejudicados pelos danos causados em seu território e/ou aos seus nacionais, a par dos embargos econômicos que aquele país já vem sofrendo.

26. Gabriclla Carclla, La Responsabilità dello Stato per Crimini Internazionali, Napoli, Jovenc, 1985, pp.14-15.

27. Cfr. Guido Fernando Silva Soares, As Responsabilidades no Direito Internacional do Meio Ambiente, Campinas, Komcdi, 1995, p.559 (Ancxo E). 
À guisa de conclusão, portanto, releva dizer que não se há debater a Justiça de uma resposta, inclusive armada, aos atentados de 11.09.2001; tampouco se há de negar o caráter criminoso de tão-hediondos atos - admitindo, inclusive, subsunção típica às fattispecies abertas do Estatuto de Roma, de 1998 (Tribunal Penal Internacional). A Justiça, porém, não transige com a qualidade do infinito (com vênia para cogitar, ainda uma vez, da primeira denominação dada às operações militares norte-americanas), porque a ação justa não se afasta dos fundamentos de sua Justiça sem se tornar inexoravelmente injusta. Uma Justiça que opere à míngua dos padrões de liceidade do mundo ocidental democrático, ignorando premissas como o devido processo legal, a racionalização da pena e o juízo de culpabilidade (ainda que adequadas, todas, à realidade unipolar da sociedade internacional; confiram-se, a propósito, os arts. 22, 23, 24, 25 e 55 do Estatuto de Roma), não será mais que torta injustiça; a ação militar que nela se fiar não será, por conseguinte, mais que uma guerra de retaliação.

São Paulo, outubro de 2001. 